\title{
The Need for Inspirational (Charismatic) Teachers in Today's Classrooms.
}

\author{
Nevila Gurra Qardaku \\ PhD Candidate at University of Tirana
}

\begin{abstract}
In the time when access to diversified and abundant information by high school students is very easy, where a student in his comfortable home via the internet, can find quick answers to his questions without having to go and stay in the class with many rules, the need for inspirational teachers is felt more than ever. The increasing number of students who do not respect the treasured figure of the teacher, and under the circumstances when the number of elements that serve as magnets to attract the students' wishes and attention at the expense of school education has increased more than ever, inspirational teachers are needed to increase the curiosity and need of the learner to explore with curiosity. The purpose of this paper is to explain the influence that inspirational teachers have on their students, based on the literature review. Conclusions: inspirational teachers are experts in their subject. They transmit enthusiasm, cultivate positive relationships with students. They are flexible, reflective and adapt to their practices, make intentional and meaningful learning for students. They also help their students to discover where their talents combine with their passions, promote a safe and stimulating climate (environment) in the classroom, create a clear and positive classroom management, developes collaboration and brings innovation to the classroom. This reflection serves to all the actors of education.
\end{abstract}

Keywords: Inspirational teachers (charismatic), today's classrooms, high school students, curiosity, expert.

\section{Introduction}

This paper addresses the issue of inspirational, charismatic teacher and the need for them in today's high school students. How is the inspirational teacher and inspirational teaching defined in the relevant literature? "Call it inspiration, creativity, or whatever you want; it is the most powerful component in learning "(Cohen \& Jurkovic 1997, cited by Derounian, 2017). Furnham points out another aspect of inspirational teachers: most teachers were inspired to choose the profession of teacher because they had an inspiring teacher who inspired them to make that choice. So, it is not genetic, but it is certainly passed on. Practically everybody has known such a person, usually a secondary school teacher or university lecturer (Furnham 2010). Through the ages, all successful educators are charismatic teachers. For them, students enjoy to get close to them and listen to their ideas. Therefore, teacher's charisma is definitely prominent in the learning process for students. If students like teachers, they would of course come to the class; if they enjoy the class, it is highly likely that they will dig deeper into this school subject (Lee, Lu, Mao, Ling, Yeh, \& Hsieh; 2014, p.1144). When students are attracted by a charismatic teacher, they enjoy learning and listening to the class (Lin, \& Huang. 2017. f. 27). In the same vein, it also defines inspirational teaching (McGonigal, 2004 cited by Derounian, 2017) that inspirational teaching "encourages you to believe in yourself... presents new perspectives that you have never dreamed of... justice tempered with compassion.

On the other hand, students who complain that classes are the longest hours for them and who do not respect the teacher's precious figure have been added. According to (Neufeld, 2005) education has become an even more stressful occupation than it was a generation or two ago. Many teachers nowadays prove that teaching is getting harder, students with less respect and disobedience, unmanageable classrooms and study achievements seem to be declining. Teachers need to be trained to facilitate learning quotes (UNESCO, 2015). The social preferences, goals, needs, and habits of today's high school students have changed a lot. Lack of motivation, disengagement and high dropout rates in various learning styles, lack of preparation of students and students for work and life in the changing conditions and needs of 21 st century jobs etc. (Cisco Systems , 2010) are some of the factors that need to be considered to adapt and take on new roles for teachers in order to make their contribution to successfully addressing these challenges. 
According to statistics, one out of five high school students in the United States drops out of school every year. The number of students who have dropped out of school has also increased in Europe. Experts believe that achieving a comprehensive reduction of school dropouts in Europe will mean re-examining the importance and applicability of the skills and knowledge learned in schools and undertaking a critical review of Europe's whole education system (TOG on ESL, 2013). Increasing the amount of information and sophistication of technology are among the biggest sources of students' multi-dimensional change and, among other things, have attracted students and captured their attention at the expense of school education.

The first challenge is to guide students more towards school-related information, and the second challenge is to teach students how to understand the vast amount of information they encounter, and in particular how to identify sources of reliable information and evaluate the reliability and validity of what they read; how to ask about the authenticity and accuracy of the information; and how to relate these new insights to prior learning and recognize their relevance to information they already understand (Facer, 2011). But these challenges cannot be successfully addressed and resolved if students do not want to stay in the classroom and if their teaching is not very appealing and they need inspiring teachers. Therefore, we need to review the content and objectives of teacher education and training. Veliu (2011) finds that; "What should be of concern to our society, and especially to teachers, parents and the Ministry of Education, is the fact that for many students, school is the most boring and disgusting thing they have to attend. Classes are the longest hours for them, and the bell is the sweetest sound in all its rudeness. "The road to realize this paper has served me personally as a deep reflection about this recent, attractive and important topic. This paper aims to offer a panorama and evidence based on literature which especially coming from empirical studies concerning (charismatic) inspirational teachers and their benefits in today's classroom.

Professor of Oxford University Center for Educational - Pamela Sammons and her colleagues, in collaboration with the Education Development Trust, have implemented a large project (study) through which they sought to understand inspirational teaching practice by drawing on different perspectives and sources of evidence. The triangular method was used in this large study:

Interviews with inspirational teachers.

Observing the classrooms where the teaching is being taught by inspirational teachers. (This includes both quantitative observation schedules and qualitative field notes)

Student ratings for their inspirational teachers (from a questionnaire survey).

These three great data sources provided rich information and unique contributions regarding inspirational teachers. (Sammons, Kington, Lindorff-Vijayendran and Ortega 2014, p.115) point out that there are strong overlaps that add to the power of our conclusions to the conclusions of these three methods used. We have already noticed that first of all, inspirational teachers strongly demonstrated the characteristics of the most effective teaching. In terms of inspirational practice in essence, we can emphasize: positive relationships, positive and supportive climate, formative feedback, high quality learning experiences, and enjoyment.

Whereas, regarding the qualities that inspirational teachers have in this study, it was concluded that inspirational teachers have and transmit enthusiasm, cultivate positive relationships with students. They are flexible, reflective and adaptable to their practices, make purposeful and meaningful learning for students. They also help their students discover where their talents combine with their passions, promote a safe and stimulating climate in the classroom, create clear and positive classroom management. Furthermore, they develop collaboration and bring innovation to the classroom and are undoubtedly experts in their subject areas. Below we will focus on elaborating the attributes of inspirational (charismatic) teachers.

It is noteworthy that these qualities of inspiring teachers are supported by many other studies, as will be noted below.

\section{Literature Review}

\subsection{Charismatic (Inspirational) Teachers have and Transmit Enthusiasm.}

As stated in the study of Sammons et al. (2014) according to interviewees, perhaps the key aspect of being an inspirational teacher is having a passion for the profession and being able to transmit that enthusiasm to their students, either for learning or for a particular subject. 
"I put enthusiasm as one of the top factors, because I genuinely think if you're enthusiastic about your job, that means your whole profession will become better... You've got to love what you do, and If you don't like what you do, you're probably not going to be good at it, it's that type of thing. So yeah, if you've got real enthusiasm to do a bit of research, go out there and see how other people do stuff, and then take things on board, and be available to, you know, hear feedback, then yeah, that's going to do it, i think, so i'm going to say enthusiasm. "(Answers to a high school teacher, selected as inspirational teacher, 6-10 years experience).

Day (2004) expressed the dictionary meaning of passion as "any feeling that strongly influences and setsthe mind in motion" (p. 11). Also According to Day (2004), passion is an important concept that should be considered in education because teaching is a profession where the teachers devote time, energy and their hearts and he argues that enthusiasm is not just an options but necessary for a qualified teaching and passion is the key to teachers to get satisfied with what they do.

Teachers who are characterized by enthusiasm and passion are generally very knowledgeable about the subject. According to (Celik 20017) passionate education requires emotional, motivational and scientific qualities and teachers, who are valued as passionate about teaching, have traits such as emotion, motivation and knowledge. Another characteristic of charismatic learning is the perception of trust in the instructor which is related to the availability and enthusiasm of the instructors (Fu, Fua \& Linb, 2014). Acording to Lammers and Murphy (2002) students are highly regarded, lecturers who are enthusiastic about their subject, inspiring, knowledgeable and helpful. Even according to the findings of the study led by Archer (1994) charismatic teachers were perceived as energetic and enthusiastic in the classroom.

\subsection{Inspirational Teachers Cultivate Positive Relationships with Students, are Flexible, Reflective, and Adapt to their Practices.}

Inspirational teachers cultivate positive relationships with students. The most important feature of excellent teachers is their passionate desire for student achievement. And this can only be achieved by ensuring classroom environment, temperament, patience, empathy and thetrust of the students (Hopkins \& Stern, 1996, quoted by Celik, 2017).

Inspirational high school teachers said adaptability was vital and that often plans could change throughout the lesson depending on the needs or interests of the class and were resilient so that strict rules would not prevent them from invading students' minds and hearts in order to increase the student's curiosity and need to explore with curiosity even in the classroom environment.

Acoording to (Michael et al. p. 23, 2016) inspirational teachers' choice from a wide range of teaching strategies and approaches, sometimes moment-by-moment, is astute as they diagnose needs and fine-tune their responses in order to deepen understanding and promote independent thought. Also, inspirational teachers are learning goal-focused although not route specific in terms of pedagogy. Learning goals are, however, never simplistic, rather they aim to take students to their next level of understanding (p. 20).

Secondary school inspiring teachers said adaptability was vital and that plans often could change throughout the lesson depending on the needs or interests of the class.

In the charismatic teacher cluster there was also a high diversity. This is also evidenced by the study. In secondary classes it was more common for this variety to involve working with different partners during the lesson, switching from whole-class discussion to group or individual activities or vice versa, and alternating between spoken and written tasks. Some teachers also provide variety by introducing novel activities or materials into their lessons (Sammons et al. 2014, p.27).

Also according to (Michael, et al. 2016) inspirational teachers had a clear view of the key priorities, but were flexible about the route required to get there and underpinned by constantly striving to improve their knowledge of learners and subject knowledge they continuously reflect on. They refine their practice.

\section{3.Inspirational Teachers make Learning Purposeful and Meaningful for Students}

Bain (2012), asked what advice would you give to a teacher who wants to become a prominent teacher - he replied - I would guess what kind of paradigms their students are likely to bring to class and to think about the kinds of questions that can engage students deeply and challenge those paradigms. 
The most important thing that makes teaching important and meaningful for high school students, especially for more mature graduates who are multi-disciplinary, is the ability of inspiring teachers to foster students' deep learning and unique personal development. This opens endless doors of mind.

Whereas (Neufeld, 2005) quotes - For teachers who value curiosity, invite inquiries, and give students' interests a prime place, independent students are a pleasure to teach. For such students, the best teachers are those who serve as mentors, fueling their interests, fostering their passions, placing them in charge of their own learning.

According to (Cisco Systems, 2010, p. 20) learning must be authentic and relevant to the context. Drawing and keeping the attention of learners means capturing them with relevant problems that make sense in their environment. In Yachana Technology High School, students in the Amazon learn skills pertinent to living in the forest, with a focus on sustainability. In India, Barefoot College focuses on deploying knowledge to provide communities with access to clean water and reliable power.

According to (Sammons et al. 2014, p. 26) all of the inspiring teachers incorporate links between lesson content and examination standards and performance, students 'daily lives beyond the classroom, popular culture, or exciting events likely to engage students' interest and attention. It was quite common for teachers to engage students actively in the process of making these connections.

\subsection{Inspirational Teachers Help their Students Discover where their Talents are Combined with their Passions}

Inspiration is a marvellous approach and it is difficult for any teacher to achieve. Exceptional teachers guide students by inspiring them to discover the intersection points of their talents and passions (Bowman, 2007). Such help received from charismatic teachers is a great advantage and it has a very positive impact on student performance, at school and why not throughout life. Chou (1997 cited by Huang \& Lin, 2013, p. 285) investigated the teacher-student relationship and suggested that teachers should pay attention to the performance of the individual self. Bain $(2012$, p. 5) points out that if each of us comes from a unique point of view that means you can develop knowledge and points of view that I would never have in my origin, and so you can be 'Einstein' and 'Shakespeare'. Thus, an important part of the creative process and learning stems from the ability to recognize the good ideas that other people have developed and to make our contributions to them.

I have written that outstanding teachers will have "tremendous success" in fostering largely deep learning approaches and achievements and this type of unique personal development. I use the term "extraordinary success" to indicate that such teachers will reach students and influence their learning goals and successes in ways that go far beyond what anyone with a particular group of students can expect - concludes Bain. An inspirational teacher can often help people find out what they are good at and passionate about. In short, they help them find their strengths (Furnham 2010).

\subsection{Inspirational Teachers Promote a Safe and Stimulating Classroom Climate}

Such a role by today's teachers is also defined by (UNESCO, 2015), which emphasizes that teachers should promote the creation of classroom environments that are respectful and secure. Also according to (Cisco Systems, 2010, p.12) learners learn new knowledge, principles, and concepts for themselves through dialogue and interaction with others, and through experimentation and risk-taking in safe environments. Indeed, learners can only develop meaningful knowledge through their interactions with each other, with teachers, and with their learning environment.

Studies argue that inspiring teachers create a positive learning environment for students, encouraging an environment where students have created confidence to express themselves freely, feel happy and secure. This again highlights the socio-emotional component of inspirational teaching combined with the more practical aspects of activities and planning.

Inspiring teachers were seen as creating safe and supportive space to learn. Inspiring teachers were seen as creating safe spaces for students to contribute and also to make mistakes. This was reflected in the feedback given when students gave erroneous answers, as well as in other students' positive and constructive responses to those instances (Sammons et al. 2014, p. 33).

\subsection{Inspirational Teachers Create Clear and Positive Classroom Management}

The inspirational teacher makes a very personal welcome to students ensuring students feel respected, secure and wanted. Most of the inspirational teachers in the interview responses referred to positive classroom management as an aspect that enabled inspiring teaching. Good classroom management, being fair, determined, and consistent were highlighted as 
prerequisites for successful teaching and learning: "[...] You must have control of your classroom. If you have no control, then never you're going to be an inspirational teacher. You have to be there, in control of it. If you haven't reached it, then you can't learn anything." Teachers also argued that good classroom management was linked to their clear academic and behavioral expectations, as well as consistency across the school and interpersonal justice, and strongly emphasized the need for a positive approach to behavior management (Sammons et al. 2014, p.17).

Acoording to (Michael et al. 2016) inspirational teachers demonstrate their qualities subtly and sometimes almost imperceptibly through the way in which they interact in the classroom and with colleagues, often unaware that what they do is exceptional and they were exceptional in being highly sensitised to multiple signals a student gives (consciously or unconsciously) then responding to it.

\subsection{Inspirational Teachers Develop Excellent Collaboration}

The practitioner-led study concluded that inspirational interaction was a key component of inspiring teaching. Such interaction was characterized by challenge, high expectations, trust and goal-focused activity and utilized a wide range of teaching strategies (Sammons et al. 2016, p. 23).

Questioning and feedback - The inspiring teachers' classes were highly interactive. Teachers place great emphasis on questioning and positive feedback to support learning. (Sammons et al. 2016, p. 27)

Circulation - Most teachers use probing questions while circulating to check for understanding and to support collaboration and communication between students. All students encouraged to contribute (Sammons et al. 2016, p. 28).

Whereas according to (Michael et al. p. 29, 2016) inspirational teachers share these elements of best practice through collaborative process:

high expectationsa fully differentiated, well planned lesson, extending prior knowledge, securing excellent progress for all students

literacy and communication are integrated into every lesson

numeracy is embedded to practice, where appropriate

motivated engaged independent students

high quality challenging tasks, supporting pace and depth of lesson

excellent developmental marking allowing students to take control of improvement

good quality questioning, extending students

differentiated homework used as a tool to develop student independence and resilience

display reflecting excellent subject knowledge that is regularly updated

excellent, planned use of additional support

\subsection{Inspiring, Charismatic Teachers Bring Innovation to the Classroom}

Inspirational teachers are so passionate about learning new things and have such a keen interest in learning new things especially about their subject that it is impossible for them to constantly innovate and stack up on their own, without serving in class to their students. Studies also emphasize this. An apassionate teacher is someone who is deeply committed to an area of knowledge or challenge in the world and who has deeply thoughtful ideas, or who has goals to develop the creativity of students coming to class every day. (Fried, 1998 cited by Celik, 2017).

Acoording to (Michael et al. p. 30, 2016) to be inspiring it was necessary to work in a context where the school did not expect that everyone would teach the same way.

Whereas according to (Sammons et al. 2014, p. 22) inspiring teachers, as well as being knowledgeable, also bring innovation into their practice and use new, modern approaches to teaching. They exploit their creativity and are willing to take some risks.An inspirational teacher asked about this. He said - I think, you know, no matter what stage you're at in 
your career you should still be doing those things, like taking a risk, not going straight for the things that are easy, or that they know." (Male, Secondary school, $0-5$ years of experience).

\subsection{Inspirational Teachers are Experts in their Subject - The Intellectual Challenge}

Inspirational teaching fires imagination through a combination of intellectual challenge, high expectations and mutual trust between teacher and learner that invites the learner to join the teacher on a journey of discovery (Michael et al. p. 17, 2016). Archer concludes out that students perceive a number of factors in their charismatic teachers, mainly personal empathy, personal intensity and intellectual challenge (Archer 2004, p. 30). But we must be mindful that charismatic teachers must also include the dimension of intellectual challenge, that is, to be experts in their subject matter, to have indepth knowledge of the subject, because otherwise it may happen what (Archer 2004, p.30-31) warns us: teachers who receive high ratings on personal empathy and personal intensity but not on intellectual challenge may generate high levels of confidence and commitment in their students, yet may lack the cognitive content necessary for good teaching. Also according to Bain (2004) who highlights in his book "What the Best College Teachers Do" - that outstanding teachers know their subjects very well. Most importantly, they know how to simplify and clarify complex, cutting-edge subject matter with thought-provoking insights, and they can think about their thinking in the discipline, analyzing its nature and evaluating its quality. Inspirational teachers shine a light on their students' minds.Also (Furnham 2010) states that inspirational teachers can light candles in the darkest minds.

\section{Inspiring Teaching Example of Typical Student Views From one School Following an Inspiring Lesson Accordingto (Michael et al. p. 28, 2016).}

(This example is brought to this paper for the purpose of illustrating the theoretical part discussed above).

"There are excellent relationships between the students and teacher, instilled by the teacher's open, personal interaction with the group and with individuals. There is humour and always respect. High levels of trust and respect ensure there is a highly positive culture for learning. The teacher has the belief the studentscan learn and communicates this. There are very clear expectations of acceptablebehaviour, for example, a clear distinction between discussion time, thinking time, one speaker/rest listening.

In turn, students are fully engaged in the lesson because they value what they are learning, and they know they will progress well. The teacher creates a verypurposeful balance between listening, explaining and doing. The students accept that they have a responsibility to both learn and to teach their group. They knowthe teacher will not answer questions, and so they ask the group. This leads to high level thinking, explaining and embeds learning.

The teacher uses very subtle techniques to ensure the culture of the classroomis highly positive and respectful. He helps the students believe in themselves and passes the responsibility for learning to the students. They trust him explicitlyand value highly the lessons because they know they will make progress. Highly sensitive to even the most subtle signals give by students and they respondsubtlety to the needs of the students. These signals illustrate both emotional needsand levels of understanding".

\section{Conclusions}

Charismatic teachers show a high degree of engagement with their students, they are proficient in their subject matter, organized, effective practitioners, and very profound in their knowledge of the subject and of the teaching methodologies through which they teach their subject.

They show an unending enthusiasm for teaching and their subjects.

They also build excellent relationships with their students and continuously promote their well-being and are highly professional, confident and reflective practitioners.

That is why we need such teachers in today's classrooms in order to draw students to lessons, despite high rates of drop out or disrespecting the teacher's precious image or other problems that today's students may have. 
Therefore, the Ministry of Education and other decision makers should develop policies and develop plans regarding the selection of charismatic, inspiring teachers whose employment will make the classroom a more loving, attractive and stimulating environment for high school students and their learning.

\section{References}

[1] Archer, A. C. (1994). The Measurement of Charismatic Teaching in the College Classroom. Paper presented at the Annual Meeting of the American Educational Research Association, 1-49.

[2] Bain, K. (2004). What the best college teachers do. Cambridge, MA: Harvard University Press.

[3] Bain, K. (2012, January 9). What the Best College Teachers Do: An HETL interview with Dr. Ken Bain. Interviewers: Patrick Blessinger and Krassie Petrova. The International HETL Review. Volume 2, Article 1, https://www.hetl.org/interview-articles/what-the-best-college-teachers-do/

[4] Blaylock, M. Churches, R. Gowers, F. Mackenzie, N. McCauley D. \& Pye. M. (2016). Inspiring teachers: how teachers inspire learners. Education Development Trust Highbridge House.

[5] Bowman, R.F. (2007) 'How can students be motivated: a misplaced question?' The clearing house: a journal of educational strategies, issues and ideas, 81(2), 81-86.

[6] Celik, B. (2017) Teaching Profession and Passion. International Journal of Social Sciences \& Educational Studies. Vol.4, No.2

[7] Cisco Systems (2010). The Learning Society: A CISCO White Paper. San Jose, Calif., Cisco Systems.

[8] Dean A. A. The lost formulae to inspiring students. Institute for interprese. Leeds Metrapolitan University.

[9] Derounian J. (2017) Inspirational teaching in higher education: What does it look, sound and feel like? International Journal for the Scholarship of Teaching and Learning. Vol. 11, No. 1, Art. 9

[10] Day, C. (2004). The Passion of Succesful Leadership. School Leadership \& Management, 24(4),425-437.

[11] Lammers, W. and Murphy, J. (2002), "A profile of teaching techniques and used in the university classroom", Active learning in Higher Education, Vol. 3 No 1, pp.54-67

[12] Michael B. Richard Ch. Fiona G. Neil M. Declan M. and M. Pye (2016). Inspiring teachers: how teachers inspire learners. Reading: Education Development Trust.

[13] Facer, K. (2011). Learning Futures: Education, Technology and Social Change. New York, Routledge.

[14] Fu, F., Fua, F. \& Linb, C. (2014) Charisma building in the e-learning classroom: an exploratory study. Procedia - Social and Behavioral Sciences 176, ( 2015 ) $683-690$

[15] Furnham, A. (2010, November 28) 'Inspire: it's the lesson that every teacher has to learn.' The Sunday Times. London. Retrieved from http://www.thesundaytimes.co.uk/sto/public/ Appointments/article461154.ece

[16] Veliu, J. (2011 Feb 16). "Schools, Problems and Challenges" Telegrafi.com, Veliu (2011). https://telegrafi.com/shkolla-problemet-dhe-sfidat/

[17] Huang, Y. C., \& Lin, S. H. (2013). Assessment of charisma as a factor in effective teaching. Educational Technology \& Society, 17 (2), 284-295.

[18] Lee, D. C., Lu, J. J., Mao, K. M., Ling, S. H., Yeh, M. C., \& Hsieh, C. L. (2014). Does teachers charisma can really induce students learning interest? Procedia: Social and Behavioral Sciences, 116, 1143-1148.

[19] Lin, S. H. \& Huang. Y. C.(2017). The Effect of Teacher Charisma on Student Attitude Towards Calculus Learning. International Journal of Science, Technology and Society. Vol. 5, No. 2, 2017, pp. 26-32.

[20] Neufeld, G. \& Mate G. (2005). Hold On to Your Kids, Publishet in the United States by Ballantine Books an imprint of the Random House Publishing Group, a divizion of Random House, Inc., New York.

[21] TWG on ESL (2013). Reducing Early School Leaving: Key Messages and Policy Support - Final Report of the Thematic Working Group on Early School Leaving Labour Force Survey 2012. Brussels, European Commission.

[22] Sammons, P., Kington, A., Lindorff-Vijayendran, A. and Ortega, L. (2016). Inspiring teachers: perspectives and practices. Summary report. Reading: Education Development Trust.

[23] Sammons, P., Kington, A., Lindorff-Vijayendran, A. and Ortega, L. (2014). Inspiring teachers: perspectives and practices. Full report. Reading: Education Development Trust.

[24] UNESCO (2015). Rethinking Education: Towards a global common good?. Paris, UNESCO. 